\title{
Breastfeeding and the Occurrence of Diarrheal Dehydration in Toddler
}

\author{
Windha Widyastuti ${ }^{*}$, Yuni Sandra Pratiwi ${ }^{2}$, Nurul Aktifah ${ }^{3}$, Isyti'aroh ${ }^{4}$ \\ 1,2,3,4 Diploma of Nursing Universitas Muhammadiyah Pekajangan Pekalongan
}

\begin{tabular}{l} 
ARTICLE INFO \\
\hline Article history: \\
DOI: \\
$\underline{10.30595 / p s h m s . v 2 i .233}$
\end{tabular}

\begin{abstract}
Dehydration which is often caused by diarrhea is the leading cause of death in children under five. The severity of diarrhea can be prevented by breastfeeding as the mother's immunity transfers to her baby. This study aimed to describe the relationship between the history of early initiation of breastfeeding, exclusive breastfeeding, and their sustainability with the occurrence of diarrheal dehydration among toddlers. This descriptive correlation study was conducted among a total sampling of toddlers undergoing inpatient due to diarrhea at the Regional Hospital of Pekalongan Regency by 61 respondents. Data were collected from August to September, 2020 , using demographic data, the history of early initiation of breastfeeding, the history of exsclusive breastfeeding, the sustainability of that variables, and the occurrence of diarrheal dehydration. Chi-Square was used to find out the relationship between the variables. This study showed that the relationship between either early initiation of breastfeeding or exclusive breastfeeding and the occurrence of diarrheal dehydration was not significant ( $p=0,092$, and $p=0,064$, respectively). Interestingly, there was a relationship between the sustainability of early initiation of breastfeeding and exclusive breastfeeding with diarrheal dehydration among hospitalized toddlers due to diarrhea $(p=0,029)$. Health care providers especially nursing in the labor room, should give more information about the importance of initiation of breastfeeding and the sustainability of it with exclusive breastfeeding among mothers after giving birth for preventing the occurrence of dehydration due to diarrhea among children in future.
\end{abstract}

This work is licensed under a Creative Commons Attribution 4.0 International License.

Early initiation of breastfeeding; $\quad$ Exclusive breastfeeding; Diarrhea; Toddler

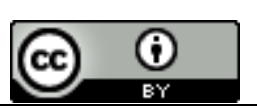

Corresponding Author:

Windha Widyastuti,

Faculty of Nursing, Muhammadiyah University of Pekajangan Pekalongan,

Jl.Raya Ambokembang No.8, Pekalongan, Indonesia

Email: windasetiadi@gmail.com

\section{INTRODUCTION}

Diarrhea is widespread in developing countries and be leading cause of death in children under the age of 5 years [15]. In Indonesia, diarrheal disease is a potential endemic disease of Extraordinary Events (KLB), and often results in death. Diarrhea is the most common cause of death in children aged 12-59 months with 314 deaths and the second cause of death in children aged 29 days with 746 deaths [16]. Data from the Central Java Provincial Health Office in 2019, states that Pekalongan Regency has a fairly low percentage of cases of diarrhea under five served at health facilities, only around $55.0 \%$. This figure is ranked 17th in Central Java Province.

Improper handling of toddlers who have diarrhea causes metabolic disorders of the body, thus it can be fatal to toddlers. These problems also may cause growth disorders, both physical and brain development of children. Repeated and long-lasting diarrhea events cause disruption of nutritional needs, with the cessation of food intake and expenditure of active nutrients that continuously occur during diarrhea, make children are at risk for malnutrition [34]. 
Various factors that can trigger diarrhea apart from clinical causes include delays in giving early initiation of breastfeeding and children not being given exclusive breastfeeding [26]. One of the efforts that can prevent children from being infected with diarrhea is to increase immunity from infancy, through breastfeeding in the first period of a child's life. Babies who are not given early initiation of breastfeeding are more susceptible to infection with diseases such as diarrhea. [19]. WHO recommends exclusive breastfeeding for infants up to 6 months of age to reduce child morbidity and mortality. Breastfeeding is recommended until the age of 2 years to meet the needs and increase the child's immunity and early initiation of breastfeeding were proven to success exclusive breastfeeding [26]. However, In the data on newborns who received early initiation of breastfeeding and exclusive breastfeeding for infants $<6$ months in Pekalongan Regency in 2019, it is known that $95.2 \%$ of newborns had early iniation of breastfeeding, only $57.2 \%$ of them continued with exclusive breastfeeding. Pekalongan Regency is a district that has the highest number in the 3rd rank of early initiation breastfeeding coverage in Central Java. The high rank in early initiation of breastfeeding coverage is not in accordance with the Exclusive Breastfeeding Coverage which is only $57.2 \%$ [9]

\section{RESEARCH METHOD}

The research design used a descriptive Correlative study. Determination of the sample will use a total sampling of 61 toddler who were hospitalized due to diarrhea in Pekalongan District Hospital. Sampling was carried out in one time data collection, namely in August-September 2020. The instrument to be used was a self report questionnaire which was fill in by the mother of children after got the information sheet and filled out the concern form of being respondent. The history of breastfeeding was shown by 2 question about the history of early initiation of breastfeeding and the history of exsclusive breastfeeding. The occurrence of diarrheal dehydration was obtained from secondary data which was the medical records of children who were hospitalized due to diarrhea in hospitals in Pekalongan Regency. Chi square for bivariate analysis to describe the reltionship between the variables.

\section{RESULT AND DISCUSSIONS}

\subsection{RESULT}

The description of the study results include a description of demographic data, description of each variable and the relationship of them. The demographic data describes the characteristic of mothers namely maternal age, job status, educational status, and place of residence that is shown in table 3.1.

Table 3.1. Distribution of the characteristics of mother $(n=61)$

\begin{tabular}{lcc}
\hline Variable & Frequency (n) & Percentage (\%) \\
\hline Age & 45 & $73,8 \%$ \\
$20-35$ & 16 & $26,2 \%$ \\
$>35$ & & \\
Job Status & 46 & $75,4 \%$ \\
Unemployee & 15 & $24,6 \%$ \\
Employee & & \\
Mother's Education & 10 & 16,4 \\
High & 22 & 36,1 \\
Intermediate & 29 & 47,5 \\
Low & & \\
Residence & 52 & 85,2 \\
Rural & 9 & 14,8 \\
Urban & & \\
\hline
\end{tabular}

Table 3.1 show that the majority of mother in reproductive age $(73,8 \%)$, mostly being a houseswife $(75,4 \%)$, had low level of education $(47,5 \%)$ and lived in rural area $(85,2 \%)$.

Table 3.2. Distribution of the history of early initiation of breastfeeding $(n=61)$

\begin{tabular}{lcc}
\hline History of Early Initiation of & & \\
Breastfeeding & Frequency $(\mathbf{n})$ & Percentage (\%) \\
\hline$<1$ hour & 33 & 54,1 \\
$>1$ hour & 12 & 19,7 \\
Never & 16 & 26,2 \\
\hline
\end{tabular}


The table describe that majority of children who are hospitalized due to diarrhea accepted early initiation of breastfeeding, only $26,2 \%$ who did not accepted this first breastfeeding in their first hours of life..

Table 3.3. Distribution of the history of exclusive breastfeeding $(n=61)$

\begin{tabular}{lcc}
\hline History of exclusive breastfeeding & Frequency (n) & Percentage (\%) \\
\hline Yes & 31 & 50,8 \\
No & 30 & 49,2 \\
\hline
\end{tabular}

The study result that shown from table 3 found that there was almost same value of the percentage of babies who get exclusive breastfeeding in their 6 months of life with babies who didn't get exclusive breastfeeding (50,8\% and 49,2\%, respectively).

Table 4. Distribution of the characteristic of diarrhea (61)

\begin{tabular}{lcc}
\hline Characteristic of diarrhea & Frequency $(\mathrm{n})$ & Percentage $(\%)$ \\
\hline No Diarrheal dehydration & 42 & 68,9 \\
Diarrheal dehydration & 19 & 31,1 \\
\hline
\end{tabular}

Table 3.4 describe that majority of hospitalized children due to diarrhea were not having dehydration $(68,9 \%)$

Table 3.5. Distribution of the sustainability of early initiation of breastfeeding and exclusive breastfeeding

\begin{tabular}{lcc}
\hline $\begin{array}{l}\text { The sustainability of } \\
\text { breastfeeding }\end{array}$ & Frequency (n) & Percentage (\%) \\
\hline Yes & 26 & $42,6 \%$ \\
No & 35 & $57,4 \%$ \\
\hline
\end{tabular}

This study found that majority of mother did not continuing the early initiation of breastfeeding with exclusive breastfeeding $(57,4 \%)$.

Table 6. The relationship between the history of breastfeeding and the occurrence of Diarrheal Dehydration

\begin{tabular}{|c|c|c|c|c|c|c|c|}
\hline \multirow[t]{3}{*}{ Variables } & \multicolumn{4}{|c|}{$\begin{array}{c}\text { Occurrence of } \\
\text { Diarrheal } \\
\text { Dehydration }\end{array}$} & \multicolumn{2}{|c|}{ Total } & \multirow[t]{3}{*}{$P$ Value } \\
\hline & \multicolumn{2}{|c|}{$\begin{array}{l}\text { Diarrhea Without } \\
\text { Dehydration }\end{array}$} & \multicolumn{2}{|c|}{$\begin{array}{c}\text { Diarrhea } \\
\text { With } \\
\text { Dehydration }\end{array}$} & \multirow[t]{2}{*}{$\mathbf{N}$} & \multirow[t]{2}{*}{$\%$} & \\
\hline & $\mathbf{n}$ & $\%$ & $\mathbf{n}$ & $\%$ & & & \\
\hline \multicolumn{8}{|l|}{$\begin{array}{l}\text { Early initiation of } \\
\text { breastfeeding }\end{array}$} \\
\hline$>1$ hour & 19 & 57,6 & 14 & 42,4 & 33 & $100 \%$ & $0,092 *$ \\
\hline$<1$ hour & 9 & 75 & 3 & 25 & 12 & $100 \%$ & \\
\hline Never & 14 & 87,5 & 2 & 12,5 & 16 & $100 \%$ & \\
\hline \multicolumn{8}{|l|}{ Exclusive breastfeeding } \\
\hline Yes & & & & & & & $0,064 *$ \\
\hline No & 18 & 58,1 & 13 & 41,9 & 31 & $100 \%$ & \\
\hline & 24 & 80 & 6 & 20 & 30 & $100 \%$ & \\
\hline \multicolumn{8}{|l|}{ The sustainability of } \\
\hline & & & & & & & $0,029 *$ \\
\hline Yes & 14 & 53,8 & 12 & 46,2 & 26 & $100 \%$ & \\
\hline No & 28 & 80 & 7 & 20 & 35 & $100 \%$ & \\
\hline
\end{tabular}

The results of the statistical test showed the relationship between either early initiation of breastfeeding or exclusive breastfeeding and the occurrence of diarrheal dehydration was not significant ( $p=$ 0,092 , and $p=0,064$, respectively). Interestingly, there was a relationship between the sustainability of early 
initiation of breastfeeding and exclusive breastfeeding with diarrheal dehydration among hospitalized toddlers due to diarrhea $(p=0,029)$.

\subsection{DISCUSSION}

Based on maternal age distribution, most mothers were in 20 to 35 years old, with $73,8 \%$. This age is the most ideal age from the aspect of health. In terms of tasks and developments stage, this age is early adulthood which is the age of reproduction. 20-35 years is the right time to give birth and breastfeeding, because that age is more mature when compared to those aged less than 20 years and has a lower risk than those over 35 years of age to experience maternal and infant mortality [21]. At that age, a mother will go through a period of trouble, a period of social tension, a period of commitment, and a period of adjustment to a new life. In addition, when mothers of toddlers are in the adult age category, they will be required to be wise about any decisions that will be taken in dealing with their toddlers if they have diarrhea. So that by taking the right decision, the mother will be able to prevent her toddler from experiencing complications of diarrhea, namely dehydration [4]. Therefore, this result in line with the occurence of the dehydration due to diarrhea, the majority of resepondents were not having dehydration due to diarrhea with $68,9 \%$.

The results of this study denoted mostly of mothers were housewife (75.4\%). These results are in accordance with data from the Ministry of Women's Empowerment and Child Protection and the Central Statistics Agency [17] that described women in the status of family mostly housewife, only $22,57 \%$ of them are employee. Housewifes means they do not work have a lot of time at home for taking care of their children. Housewifes have the opportunity to continue maintaining the health of their families, especially children. Mothers will have more opportunities to exclusively breastfeed compared to working mothers [6]. This opportunity of housewife may relief of diarrhea symptoms experienced by children that prevent the severity as the result of occurence dehydration among respondent were low $(31,1 \%)$.

A person's level of education can increase his knowledge about health. One of the factors that affect a person's knowledge is the level of education. Education will provide knowledge so that the alteration of positive behavior may occur [22]. The results of the study based on mother's education showed that most of the mothers $(53.2 \%)$ were in the low category of the level of education. With a low level of knowledge, a mother tends to find the difficulties to protect and prevent her toddler from transmitting diarrhea. This low knowledge causes mothers to have their own and different views on diarrheal disease.

The description of respondents based on residence showed $90.3 \%$ of respondent who are hospitalized due to diarrhea live in rural areas. This area may cause the barrier to access health services, so that people do not get enough information related to health or utilize the health facilities. Moreover, the data from Indonesian health profil in 2019 also showed that there were more fewer children who accepted erly initiation of breastfeeding in rural area rather than in urban area [16]. Breastfeeding in the first hour of life is able to provide the child's immune system to prevent infectious diseases especially in the gastrointestinal system such as diarrhea [19]

Toddlers are more at risk for diarrhea than adults. Toddlers have a body composition that contains more water than adults, so toddlers are more susceptible to diarrhea. This age group has at least $2-3$ episodes of diarrhea per year [35]. If toddlers have diarrhea, they will be more at risk exposed to dehydration and other complications that can lead to malnutrition and even death. The main cause of diarrheal death is dehydration due to loss of fluids and electrolytes through feces. For toddlers with Prolonged diarrhea exposure will cause dehydration. Dehydration due to diarrhea depends on the percentage lost body fluids [35]. The mother's role is very important in the incidence of diarrhea in toddlers because if the toddler has diarrhea then mother will take some related actions treatment and care efforts [4,5]. The role of mothers in preventing the severity of diarrhea, one of it is behavioral [32]. The study from Luthfiana and Utami stated that the third factors that influence the incidence of diarrhea is breastfeeding such a behavioral factors.

This study result that show in Table 2 described that majority of hospitalized children due to diarrhea accepted early initiation of breastfeeding in their first hour of live $(73,8 \%)$. This study also describe that early initiation of breastfeeding and diarrheal dehydration was not significant $(p=0,92)$. In contrast, previouse study in A case study from Surabaya by [20] showed that there was a negative relationship between initiation practices early breastfeeding initiation and diarrhea. Baby who had diarrhea in the first time at the age of three days were from the mother who do not carry out early breastfeeding initiation and the baby has diarrhea the first time at the age of 90 days in the mother who carry out the early breastfeeding initiation. The presence of immunity that children get from breast milk particularly colostrum will reduce the possibility of children getting diarrhea and the severity of diarrhea.

Breast milk given first time in babies called Colostrum is very useful and plays a role as the first vaccine in infants so that will provide protection against various diseases thus it will reduce children to get gastrointestinal infections such as diarrhea [23]. Judging from the time of colostrum release, based on the previouse research from Pesawaran regency that found there were 19 out of 24 (79.2\%) mothers who did

Proceeding homepage: https://conferenceproceedings.ump.ac.id/index.php/pshms/issue/view/10 
IMD experienced rapid colostrum expulsion time while mothers who did not do IMD there were 9 out of 24 (37.5\%) who experienced rapid colostrum expulsion time [39]. The protein content of colostrum is more than that of mature breast milk, but its carbohydrate and total energy content is lower than that of mature milk. Colostrum contains 10-17 times more anti-infective substances than mature breast milk. In addition, colostrum is an ideal laxative fluid to clear unwanted substances from the newborn's intestines and prepares the baby's digestive tract for the food to come.

However, this study revealed that $26,2 \%$ baby did not accept early initiation of brestfeeding. This might happen because of many reasons. Condition mothers who are tired after giving birth and not accompanied by family during the process giving birth and also knowledge of mothers who less about the benefits of breastfeeding being the reasons of no early initiation of breastfeeding [30]. The reasons of mother delay early initiation of breastfeeding, such as the level of education of the mother and the level of mother's socioeconomic status [11]. Influence situation also plays an important role in successful initiation of early breastfeeding [30]. Another belief that Breast milk will not be available until three days postpartum is another common reason for mothers to delay early initiation of breastfeeding, then give formula for baby. Previous studies have reported that the introduction of complementary foods and formula feeding increases the risk of food-borne infections [1]). It has been reported that several higher episodes of childhood diarrhea are associated with poor sanitary conditions and hand washing practices [3].

The result of this study also found that there was no relationship between exclusive breastfeeding with the occurence of diarrheal dehydration by $p=0,64$. This result in line with the previouse study from Majalengka that described no relationship between exclusive breastfeeding with the severity of diarrhea $(p=0,933)$ [13]. Similarly, a previouse study in Bandung (2015) described the severity of diarrhea which is the occurence of dehydration due to diarrhea in infants who were exclusive breastfeed was not significantly different from infants who not received [25]. In line with other previouse studies, namely a study in Uganda that explained the protection of exclusive breastfeeding against rotavirus diarrhea were low. Study showed different results in the relationship between exclusive breastfeeding and rotavirus diarrhea, not all showing benefits from exclusive breastfeeding in reducing the severity [10]. Otherwises, exclusive and habitual breastfeeding were a behavioral factor that influences the spread of enteric germs and reduces the risk of diarrhea [31]. In that study showed the relationship between exclusive breastfeeding and diarrhea in infants under 3 years. Babies who were not exclusively breastfed mostly suffered from diarrhea (52.9\%), while infants who received exclusive breastfeeding, only $32.31 \%$ suffered from diarrhea.

However, The specific role of breastfeeding in the prevention of rotavirus diarrhea has not been well established; however, it is generally considered that it at least reduces the severity of the disease. Several previous studies that support the positive influence of exclusive breastfeeding on the incidence of diarrhea include a study in Malaysia in 2012 that claimed a relationship between breastfeeding and protection against rotavirus diarrhea [24]. Early breastfeeding initiation is very important not only for the survival of newborns but also in determining the success of breastfeeding activities in the long term, namely the success of exclusive breastfeeding [14]. Based on the results of this study, 54,1\% of baby who got early initiation of breasetfeeding only under 1 hour. A previouse study in 2013 stated that infants who received breast milk for the first time in the first hour after birth, it was shown that 42.8 percent were still exclusively breastfed and 57.2 percent were not exclusively breastfed. Meanwhile, of the infants who received their first breast milk more than 1 hour after birth, it showed that there were $65.7 \%$ who were not exclusively breastfed and $34.3 \%$ who were still breastfed exclusively. Midwives who support childbirth should be able to help mothers provide a sense of security and comfort after the delivery process and provide motivation so that mothers are ready to give birth then breastfeed the baby for at least 1 hour, so that the early initiation of breastfeeding process can run well [21].

Early breastfeeding initation should become a routine for support successful breastfeeding exclusive, subsequent and prolonged milk production breastfeeding. In contrast, this study result stated that majority of mother $(57,4 \%)$ were not have the sustainability of early initiation of breastfeeding with exsclusive breastfeeding. This result is incoherence with several previouse studies. In accordence, a study in Sumatra Utara in 2018 among 66 post partum mother that examine a cross-exclusive breastfeeding based on the implementation of early initiation of breastfeeding. The results showed that from 39 respondents who carried out early initiation of breastfeeding, 23 respondents (59.0\%) gave exclusive breastfeeding to their babies and 16 respondents $(41.0 \%)$ did not give exclusive breastfeeding to their babies. Meanwhile, of the 27 respondents who did not carry out early initiation of breastfeeding, as many as 6 respondents (22.2\%) gave exclusive breastfeeding to their babies and 21 respondents $(77.8 \%)$ did not give exclusive breastfeeding to their babies [8].

To increase the success of exclusive breastfeeding, it is necessary to increase milk production. Based on related research that conducted among 15 post partum mothers who carry out Early breastfeeding initation and 15 post partum mothers who did not carry out Early breastfeeding initation. The study found a 
relationship between early initiation of breastfeeding with milk production to post partum mothers in Mranggen Village Jatinom District, Klaten by $\mathrm{p}=0.000$ [2]. However, the production of breastmilk can be prepared during pregnant, then carry out the breastfeeding to the baby immediately after the baby is born, and breastfeeding the baby as often as possible. The more often the baby sucks the nipple of mother's milk, the more milk comes out so that the baby can breastfeed exclusively for 6 months without food and drink other than breast milk itself [31].

According to the World Health Organization (WHO) and the United Nations Children's Fund (UNICEF), infants are expected to immediately breastfed within 1 hour after birth then continued to accepting exclusive breastfeeding for the first 6 months of the baby's life. The introduction of nutritious food to infants is carried out after 6 months accompanied by breastfeeding until the age of 2 years. Therefore, WHO recommends exclusive breastfeeding for infants up to 6 months of age to reduce child morbidity and mortality. Breastfeeding is recommended to be continued until the age of 2 years to meet the needs and increase the child's immunity to prevent infectiouse disease among children such as diarrhea [26]. As the result of this study that found a significant relationship between sustainability of breastfeeding with the occurence of diarrheal dehydration with $p=0,029$.

Breast milk is not contaminated and has content that is in accordance with the child's needs accompanied by immunity that is able to block the entry of antigens and prevent the baby from being exposed to various kinds of infections, especially gastrointestinal disorders due to the presence of gastrointestinal protective substances in breast milk [15]. This role of the mother is very important in the incidence of diarrhea in toddlers because if the toddler has diarrhea, the mother should take several actions related treatment and care efforts to prevent the severity of diarrhea [5]. The efforts that have been made by the mother will also greatly determine the course of her child's illness. As the result of the study, The role of mother such as giving baby early initiation of breastfeeding which is continuced to exclusive breastfeeding to prevent or decreaseing the severity of diarrhea.

\section{CONSLUSION}

The conclusion of this study is the relationship between either early initiation of breastfeeding or exclusive breastfeeding and the occurrence of diarrheal dehydration was not significant $(p=0,092$, and $p=$ 0,064 , respectively). Interestingly, there was a relationship between the sustainability of early initiation of breastfeeding and exclusive breastfeeding with diarrheal dehydration among hospitalized toddlers due to diarrhea $(p=0,029)$.

\section{Acknowledgements}

The authors wish to express our deep thanks to all respondents who involved in this research. The authors are deeply indebted to all who were actively engaged directly or indirectly for completing this study on time

with their kindness and helps.

\section{REFERENCES}

[1] Agustina, R.; Sari, T.P.; Satroamidjojo, S.; Bovee-Oudenhoven, I.M.; Feskens, E.J.; Kok, F.J "Association of food-hygiene practices and diarrhea prevalence among Indonesian young children from low socioeconomic urban areas, "BMC Public Health, vol. 13 , no. 977, 2013.

[2] Arini, Meilani Yudi, 2012, "Hubungan Inisiasi Menyusu Dini Dengan Produksi Asi Pada Ibu Post Partum Di Desa Mranggen Kecamatan Jatinom Klate.," Jurnal Komunikasi Kesehatan. vol. 4, no. 2, 2013.

[3] Bitew, B.D.; Woldu, W.; Gizaw, W, "Childhood diarrheal morbidity and sanitation predictors in a nomadic community," Ital. J. Pediatrics, vol. 43, no. 91, 2017.

[4] Christy, MY. "Faktor yang Berhubungan dengan Kejadian Dehidrasi Diare pada Balita di Wilayah Kerja Puskesmas Kalijudan. Jurnal Berkala Epidemiologi," vol. 2, no. 3, p. 297-308, 2014.

[5] Christie G. Turin, MD and Theresa J. Ochoa, MD, "The Role of Maternal Breast Milk in Preventing Infantile Diarrhea in the Developing World," Curr Trop Med Rep, vol. 1, no. 2, p. 97-105, 2014.

[6] Dahlan, A., Mubin, F., Mustika, D.N, "Hubungan Status Pekerjaan dengan Pemberian ASI eksklusif di Kelurahan Palebon Kecamatan Pedurungan Kota Semarang," Jurnal Kebidanan Universitas Muhammadiyah Semarang, vol. 1, no. 1, p. 1-5, 2013.

[7] Damayanti, W, "Analisis pelaksanaan inisiasi menyusu dini (imd) di puskesmas kabupaten tangerang provinsi banten.," Indonesian Midwifery Journal, vol. 1, no. 2, 2018. 
[8] Deonita G, "Gambaran Pelaksanaan Inisiasi Menyusui Dini (IMD), Pmberian ASI Eksklusif dan Status Gizi Bayi di Wilayah Kerja Puskesmas Pegagan Julu II.," Skripsi Fakultas Ilmu Kesehatan Universitas Sumatera Utara, Medan, 2018.

[9] Dinas Kesehatan Provinsi Jawa Tengah, Profil Kesehatan Provinsi Jawa Tengan, Semarang : Dinas Kesehatan Provinsi Jawa Tengah, 2019.

[10] E. Wobudeya, H. Bachou, C. K. Karamagi, J. N. Kalyango, E. Mutebi, and H.Wamani, "Breastfeeding and the risk of rotavirus diarrhea in hospitalized infants in Uganda: a matched case control study," BMC Pediatrics, vol. 11, 17, p. 7, 2011.

[11] Garcia CR, Mullany LC, Rahmathullah L, Katz J, Thulasiraj RD, Sheeladevi S, et al. "Breast-feeding initiation time and neonatal mortality risk among newborns in South India," J Perinatol [Internet]. 31 ( 6); 397-403, 2010

[12] Hanieh S, Ha TT, Simpson JA, Thuy TT, Khuong NC, Thoang DD, et al. "Exclusive breast feeding in early infancy reduces the risk of inpatient admission for diarrhea and suspected pneumonia in rural Vietnam: a prospective cohort study," p. 1-10, 2015

[13] Irawan TA, "Faktor Faktor Yang Mempengaruhi Kejadian Diare Pada Balita Di Wilayah Kerja UPTD Puskesmas Raja Galuh Kabupaten Majalengka Tahun 2015," Jurnal Keperawatan dan Kesehatan MedisnaAkper YPIB Majalengka, vo. 2, no. 3, 2016.

[14] Karimi FZ, Miri HH, Salehian M, Khadivzadeh T, and Bakhshi M, "The Effect Of Mother Infant Skin To Skin Contact After Birth On Third Stage Of Labor : A Systematic Review And Meta Analysis," Iran J Public Health, vol. 48, no. 4, p. 612-620, 2019

[15] Kemenkes RI. (2013). Situasi Diare. Kementrian Kesehatan RI.

[16] Kementerian Kesehatan RI, Profil Kesehatan Indonesia Tahun 2019. Jakarta: Kementerian kesehatan, 2020

[17] Kementerian Pemberdayaan Perempuan dan Perlindungan Anak. Profil Perempuan Indonesia 2019.Jakarta : Kementerian Pemberdayaan Perempuan dan Perlindungan Anak

[18] Luba, S., Gambaran Pelaksanaan Inisiasi Menyusu Dini Di Rumah Sakit Ibu Dan Anak Pertiwi Makassar Tahun 2019. Jurnal Farmasi Sandi Karsa, vol. 5, no. 1, p. 90-94., 2019

[19] Matondang C.S., Munatsir Z., Sumadiono. (2008). Aspek Imunologi Air Susu Ibu. In : Akib A.A.P., Munasir Z., Kurniati N (eds). Buku Ajar AlergiImunologi Anak, Edisi II. Jakarta : Badan Penerbit IDAI, pp: 189-202

[20] Minarsih, \& Adiningsih, S. (2013). Hubungan Praktek Inisiasi Menyusu Dini Dengan Kejadian Diare, 6-12.

[21] Mumpuni, RS and Utami, ED. Pengaruh Menyusui Dini (IMD) dan Faktor Sosial Demografi terhadap Ketahanan Pemberian ASI Eksklusif. E-Jurnal WIDYA Kesehatan dan Lingkungan 2016;1(2): 116-121

[22] Notoatmodjo, S. 2003. Pendidikan Dan Perilaku Kesehatan. Rineka. Cipta. Jakarta

[23] Ogbo FA, Agho K, Ogeleka P, Woolfenden S, Page A, Eastwood J, et al. Infant feeding practices and diarrhoea in sub- Saharan African countries with high diarrhoea mortality. 2017;1-17

[24] Prameela and L. R. Vijaya, "The importance of breastfeeding in rotaviral diarrhoeas," Malaysian Journal of Nutrition, vol. 18, no. 1, pp. 103-111, 2012.

[25] Prassetyo D, Sabaroedin LM, Ermaya YS, and Soenarto Y, “Association between severe Dehyfration in Rotavirus Diarrhea and Exclusive Breastfeeding among Infants at Dr. Hasan Sadikin General Hospital, Bandung, Indonesia," J Trop Med, 2015

[26] Rahayu A, Rahman F, Marlianae L, Husaeni, Meitria, Yulidasari F, Rosadi D and Laily N (2018) GIZI 1000 HARI PERTAMA KEHIDUPAN. CV Mine, Banjarmasin. ISBN 978-60252209-9-9

[27] Rahmadhani E.P., Lubis G., Edison. Hubungan pemberian ASI eksklusif dengan angka kejadian diare akut pada bayi usia 0-1 tahun di Puskesmas Kuranji Kota Padang. Jurnal Kesehatan Andalase. 2013,2 (2)

[28] Saragih. E.C., Hubungan Pemberian Inisiasi Menyusui Dini Dan Asi Dengan Daya Tahan Tubuh Pada Bayi Diposyandu Wilayah Kerja Puskesmas Saran Padang Kecamatan Dolok Silau Kabupaten Simalungun Tahun 2017. 2017.Skripsi : Poltekes Kemenkes Medan

[29] Shati, A.A., Khalil, S.N., , Asiri, K.A., Alshehri, A.A., ,Deajim, Y.A., Al-Amer, M.S., Alshehri, H.J., Alshehri, A.A., and Alqahtani, F.S. Occurrence of Diarrhea and Feeding Practices among Children below Two Years of Age in Southwestern Saudi Arabia. Int. J. Environ. Res. Public Health 2020, 17, 722; doi:10.3390/ijerph17030722

[30] Sirajuddin, S., Abdullah, T., \& Lumula, S. N. (2013). Determinant of the Implementation Early 
breastfeeding initiationInitiation. Jurnal Kesehatan Masyarakat Nasional, 8, (3), 99-103.

[31] Tauriska TA, \& Umamah F, "Hubungan antara Isapan bayi dengan produksi ASI pada Ibu Menyusui di Rumah Sakit Islam Jeruk Sari Surabaya,” Jurnal Ilmu Kesehatan, Vol. 8, no. 1, 2015

[32] Utami N, Luthfiana N, "Faktor faktor yang mempengaruhi diare pada anak," Medical Journal of Lampung University, vol.5 no. 4, 2016

[33] Victora, C.G.; Bahl, R.; Barros, A.J.; França, G.V.; Horton, S.; Krasevec, J.; Murch, S.; Sankar, M.J.; Walker, N.; Rollins, N.C.; et al. Breastfeeding in the 21st century: Epidemiology, mechanisms, and lifelong effect. Lancet 2016, 387, 475-490. [CrossRef]

[34] Wibowo, Hardiyanti, and Subhan, "Hubungan dehidrasi dengan komplikasi kejang pada pasien diare usia 0-5 tahun di RSD Idaman Banjarbaru”, Jurnal Kebidanan dan Keperawatan. Vol. 10, no. 1, 2019.

[35] Widoyono. Penyakit Tropis : Epidemiologi, Penularan, Pencegahan, dan Pemberantasannya. Jakarta: Erlangga; 2011.

[36] Wiknjosastro, Hanifa.2008.Asuhan Persalinan Normal.Jakarta:Depkes R

[37] ___ _.2008.Asuhan Persalinan Normal dan Inisiasi Menyusui Dini. Jakarta:Depkes RI

[38] World Health Organisation. Infant and Young Child Feeding. 2009. Available online: https://www.who.int/nutrition/publications/infantfeeding/9789241597494.pdf $\quad$ (accessed on 12 September 2020).

[39] Yenie H and Mugiati. Hubungan Inisiasi Menyusui Dini (IMD) dengan Waktu Pengeluaran Kolostrum. Jurnal Keperawatan; XI(2):299-304 